\section{DIPHTHERIA IN THE TROPICS}

\section{A SUBCLINICAL DISEASE IN NEGROES}

BY

GEORGE KINNEARD, M.D.

BACTERIOLOGIST AND MEDICAL OFFICER, BAHAMAS GENERAL HOSPITAL

Though diphtheria is considered to be uncommon in the Tropics, it does occur in tropical latitudes every year. The following table gives the evidence of this disease as recently reported in a supplement to the Tropical Diseases Bulletin. ${ }^{1}$ It covers 1931, which is probably quite a representative year.

\begin{tabular}{|c|c|c|c|c|c|c|c|c|}
\hline \multirow{2}{*}{\multicolumn{4}{|c|}{ Country }} & \multirow{3}{*}{$\frac{\text { Population }}{-}$} & \multicolumn{2}{|c|}{ Cases } & \multicolumn{2}{|c|}{ Deaths } \\
\hline & & & & & \multirow{2}{*}{$\frac{1931}{183}$} & \multirow{2}{*}{$\begin{array}{r}1970 \\
68\end{array}$} & \multirow{2}{*}{$\frac{1931}{-}$} & \multirow{2}{*}{$\frac{1930}{-}$} \\
\hline Sudan ... & $\ldots$ & $\ldots$ & $\ldots$ & & & & & \\
\hline Ceylon ... & $\ldots$ & $\ldots$ & $\ldots$ & $4,504,599$ & 68 & 86 & 29 & 30 \\
\hline Federated & Iala & Sta & $3 \ldots$ & $1,324,890$ & 143 & 112 & 28 & 31 \\
\hline Straits Sett1 & eme & & $\ldots$ & - & - & - & 43 & 31 \\
\hline Hong-Kong & $\ldots$ & $\ldots$ & $\ldots$ & $1,143,510$ & 231 & 95 & - & - \\
\hline Barbadoes & $\ldots$ & $\ldots$ & ... & 120,391 & 9 & - & - & - \\
\hline
\end{tabular}

This table brings out three points. (1) The case in cidence for the populations exposed to risk is quite low if no cases were missed. (2) The proportion of deaths to cases indicates a high mortality rate. (3) The marked absence of reported cases in those parts of the Empire which have a predominantly negro population-that is, Africa and the West Indies-is a notable feature.

\section{The Disease in Negroes}

The following observations tend to offer some measure of explanation for this variation in prevalence, more especially in regard to the negro. As a basis for discussion certain well-known postulates may be mentioned: (1) A case of diphtheria indicates infection overcoming host resistance. (2) The existence of "carriers" indicates resistance to virulent organisms. (3) A negative Schick reaction, unless artificially produced, indicates one or more prior infections which, if a negative history of diphtheria be present, have been subclinical in character.

\section{Negro Resistance}

The relative infrequency of diphtheria in the negro may be attributed to a greater resistance.

The best evidence for this is available in the Southern States of the U.S.A. Here, a large coloured population lives uncier mainly the same conditions as the white population. Doull ${ }^{2}$ gives the following table of mortality rates in white and negro races for the years 1917-24 in ten States of the U.S. registration area.

\begin{tabular}{|c|c|c|c|c|c|c|}
\hline \multicolumn{7}{|c|}{ TABIE II* } \\
\hline \multirow{2}{*}{\multicolumn{4}{|c|}{ States }} & \multirow{2}{*}{$\begin{array}{l}\text { Period } \\
\text { Ineluded }\end{array}$} & \multicolumn{2}{|c|}{$\begin{array}{c}\text { Average Annual Mortality } \\
\text { per } 100,00 j\end{array}$} \\
\hline & & & & & Whites & Negroes \\
\hline Kentucky & $\ldots$ & $\ldots$ & $\ldots$ & $1917-\approx 4$ & $\quad 15.9$ & 10.7 \\
\hline Virginia... & $\ldots$ & $\ldots$ & ... & $"$ & 14.5 & 8.1 \\
\hline Mississippi & $\ldots$ & $\ldots$ & $\ldots$ & , & 13.6 & 8.8 \\
\hline Maryland & $\ldots$ & $\ldots$ & ... & " & 135 & 7.5 \\
\hline Tennessee & $\ldots$ & $\ldots$ & $\ldots$ & $\infty$ & 13.3 & 9.0 \\
\hline Nerth Carol & & $\ldots$ & $\ldots$ & $\infty$ & 12.1 & 7.9 \\
\hline Georgia ... & $\ldots$ & $\ldots$ & $\ldots$ & . & 11.1 & 7.3 \\
\hline South Carol & ina & $\ldots$ & ... & $"$ & 11.1 & 6.1 \\
\hline Florida ... & $\ldots$ & $\ldots$ & $\ldots$ & " & 10.2 & 4.3 \\
\hline Louisiana & $\ldots$ & $\ldots$ & &.. & 7.4 & 5.3 \\
\hline
\end{tabular}

* The rates are adjust d for differer: $c s$ in age constitut on beiween populatious concerned, the population of the Contiuental Uliied States i.1 1920 being taken as a standard.
This table would appear to show that: (a) mortality rates in both races tend to be lower in lower latitudes: (b) mortality rates in the negro races are strikingly lower in every State listed. The same observer has been able to show that in Baltimore " morbidity rates from diphtheria in recent years have been less than one-third as high for the negro as for the white population." $\mathrm{He}$ states further that the difference can hardly be due to poorer repcrting of negro cases, since in the public schools zases in both races stand about an equal chance of recognition, so that if cases in negroes were missed it must have been because they were mild in character-again indicating the superior resisting power of the negro to this infection.

\section{Prevalence of Infection}

The relative infrequency of diphtheria in the negro race is NOT due to absence of infection in the Tropics.

Wherever in the Tropics the subject has been studied, C. diphtheriae has been isolated from throat cultures.

Thus Gomez and Navarro (Manila, 1923) cultured the throats of 1,222 children, finding five carriers. A further series of 2,843 cultures, undertaken at Singapore in 1931, resulted in 145 positives. Again, Garrido-Morales (Porto Rico, 1931) cultured 642 children and found nine carriers.

The writer secured cultures from 300 coloured children in Nassau, Bahamas, aged from 1 to 10 , with four carriers. Cultures were taken from the tonsils and grown on Loeffler's blood serum. Subsequently this culture was transplanted to tellurite-serum agar for purposes of isolation. The number of carriers of virulent bacilli when cultures are taken from a random sample of children in the Tropics, as indicated in these observations, show an incidence in Manila of $\mathbf{0 . 4}$ per cent., in Porto Rico of 1.4 per cent., and in Nassau, Bahamas, of 1.3 per cent. In Singapore 5 per cent. of specimens submitted were positive, but these came from hospitals, and presumably represent a selected group. Doull and Fales ${ }^{3}$ (1923) in three surveys of Baltimore children found a mean incidence of 1.75 per cent.

It will be seen therefore that the organism exists in tropical areas almost as frequently as in northern areas, and in two of the regions cited there is a relatively large coloured population. Although I have isolated the organism from the throats of coloured children in Nassau, diphtheria has never, in so far as I am aware, been reported in a coloured patient. The disease, however, is observed among the whites and has caused some deaths. "The condition known as " veld sore," " septic sore," " desert sore," "Barcoo rot," which is prevalent in some parts of the Tropics and is said to be due to $C$. diphtheriae, suggests that in these latitudes the organism may exist as a saprophyte. Manson-Bahr ${ }^{4}$ states that he observed the condition during the war among men of mounted units, especially those associated with camels, and that the sores appeared mostly on exposed areas covered by hair (dorsum of the hand, forearm, etc.). In South Africa it is familiar to sportsmen and travellers.

\section{A Subclinical Disease}

The relatively high frequency of immunes among negroes in the Tropics indicates, in the absence of reported cases, that diphtheria tends to be a subclinical disease in this race.

During the past ten years a great many observers have carried out Schick tests on groups of individuals living in the Tropics and subtropics. These studies have been made on many different races-the Portuguese in Brazil, the Filipinos in Manila, the Malays, Chinese, and Indians in the Federated Malay States, and the aborigines in East Africa. In every case these investigations have brought out the fact that there is a high frequency of immunes in the Tropics, and some investigators have been able to demonstrate the mechanism of natural immunity.

Thus Harries ${ }^{5}$ (1927) observed four Schick-positive individuals who were " carriers" of virulent diphtheria organisms, and who became Schick-negative during the course of three weeks. Garrido-Morales ${ }^{6}$ (1931) observed 194 Schickpositive children for a period of three months. At the end of this per:od he found that 20.1 per cent. had become Schicknegative. 
During March of 1934 the writer was able to Schicktest a random sample of 300 coloured children, and also a small group of white children in Nassau, Bahamas. The results in the coloured group are shown in Table III and in the white group in Table IV.

\begin{tabular}{|c|c|c|c|c|c|}
\hline \multicolumn{6}{|c|}{ Results } \\
\hline \multicolumn{2}{|c|}{ Material } & \multicolumn{2}{|c|}{ Negative } & \multicolumn{2}{|c|}{ Positive } \\
\hline Males & Females & Males & Females & Males & Females \\
\hline 148 & 180 & $94.1 \%$ & $87.2 \%$ & $5.9 \%$ & $12.8 \%$ \\
\hline \multicolumn{2}{|c|}{ Total 328} & \multicolumn{2}{|c|}{$95.27 \%$} & \multicolumn{2}{|c|}{$9.23 \%$} \\
\hline \multicolumn{6}{|c|}{ TABLE IV } \\
\hline \multirow{2}{*}{\multicolumn{2}{|c|}{ Material }} & \multicolumn{4}{|c|}{ Results } \\
\hline & & \multicolumn{2}{|c|}{ Negative } & \multicolumn{2}{|c|}{ Positive } \\
\hline Males & Females & Males & Females & Males & Females \\
\hline 16 & 26 & $66.6 \%$ & $57.1 \%$ & $33.4 \%$ & $42.9 \%$ \\
\hline Total & 2 & & $\%$ & & $\%$ \\
\hline
\end{tabular}

It will be seen, therefore, that in the coloured group some 90 per cent. were negative, while in the white group just over 60 per cent. were negative. It is true that the numbers-especially in the white group-are quite small, but in both cases they represent random samples of the population at the ages of from 1 to 10 , and I am of the opinion that the examination of larger groups would not show very different results.

The evidence presented has, I think, some interest to the physician who has charge of white children in a tropical area such as the West Indies, where a large coloured population lives alongside a very small white population. Years may pass without a single case being reported, yet the organism may be present, and when a case crops up in a white child the diagnosis may readily be missed.

\section{Summary}

1. The negro resists infection with $C$. diphtheriae better than the white.

2. C. diphtheriae can be isolated from the throats of coloured children in areas where no cases are reported.

3. Schick tests reveal a high degree of antitoxic immunity in coloured populations.

4. Diphtheria is an ever-present peril to the white child in the Tropics.

5. Evidence is submitted .which tends to show that diphtheria among coloured persons in the Tropics tends to be subclinical.

${ }^{1}$ Trop. Dis. Bull., Supplement, October, 1933.

2 Doull, James A.: Journ. Prevent. Med., iv, No. 5, September, 1930

Doull, J. A., and Fales, W. T.: Amer. Journ. Hyg., 1923, iii, 604.

Manson-Bahr: Manson's Tropical Diseases, 1929, ninth edition.

'Harries, E. H. R.: Proc. Roy. Soc. Med., 1927, xxi, 11.

'Garrido-Morales, E., and Mandry, O. C.: Mechanism of Natural Immunity to Diphtheria, 1931.

G. Gouverne (Thèse de Paris, 1934, No. 830), who records a personal case of enterococcus meningitis secondary to influenza in a man aged 28 , with a review of the literature, states that the former is a rare affection. The subjects are usually young persons. The condition is rarely primary, but is, as a rule, secondary to a previous infection, such as influenza, some digestive disturbance, or a suppurative focus in the cranio-facial region. Although the enterococcus is often the only organism found, it may be associated with others, such as the meningococcus, tubercle bacillus, or Micrococcus catarrhalis. The prognosis is very grave, as the issue is almost always fatal. The diagnosis is impossible clinically, and can only be made by bacteriological examination.

\section{Clinical Memoranda}

\section{Haemorrhage during Operations, Especially Thyroidectomy}

Surgeons differ greatly in their concern for the amount of blood a patient loses during operation. I well remember thirty years ago watching a very eminent brain surgeon performing a craniotomy to remove the Gasserian ganglion; he turned down a big scalp flap with absolutely no regard for the arteries spurting in all directions, left them for the house-surgeon to pick up as best he could, and went on with the trephining. On the other hand, there is Lord Moynihan's story of the distinguished visitor from the Continent watching him carefully secure every vessel in an abdominal operation before cutting it, and remarking, "And is British-blood then so precious?" Unquestionably, many patients who have been alleged in the past to have died of shock were really the victims of too severe a loss of blood, which could and should have been prevented. Of late years, especially during operation for the removal of the thyroid gland for thyrotoxicosis, it has been the custom in my practice to keep a roughly accurate measure of the quantity of blood lost. Fortunately, in this operation there are several possible halting places: one may terminate the surgical procedure after tying the superior thyroid artery, or again after securing the inferior thyroid, or after a hemithyroidectomy, and again after following the same steps on the other side; that is to say, there are five possible halts short of a bilateral subtotal thyroidectomy. Up to about fifteen ounces the loss of blood is well borne; after twenty ounces there are usually definite signs of danger ; it is unjustifiable to go on doing more, if a halt is possible, when the loss exceeds twentyfive ounces.

The method of estimation is quite simple. Before operation the weight of, say, twenty ordinary gauze swabs is ascertained by weighing. After the sterile cloths have been laid around the neck the whole area where blood may trickle down is well packed with plenty of swabs. The haemorrhage is kept sufficiently under control to ensure that none gets on the surgeon's gown or on the floor. From time to time the swabs used for mopping. and those packed round the neck, are given to a dresser to be counted and weighed; a simple calculation gives the weight of the swabs and the weight of the blood. Usually a little soaks into the sterile cloths, and one has to add an ounce or two to cover this. The loss of time during the operation is practically nil; the margin of safety obtained is considerable. In the majority of cases the amount of blood lost is about ten ounces; it may be as low as three or as high as twenty-five.

Operations on the neck call for a far more studied care in haemostasis than is usual in other parts of the body, or there may be very serious bleeding from an insecurely tied vessel after the patient has gone back to bed. It is my practice to transfix, with a curved needle and catgut, all but the tiniest vessels, to use a three-cast instead of a two-cast knot, to tie. the big arteries twice over, and to ask the anaesthetist to let the patient come round and cough or strain vigorously before closing the skin incision.

There should be a special nurse in attendance for at least twelve hours. If these precautions are observed the old bugbear of reactionary haemorrhage need be feared no longer.

Department of Surgery,

A. Rendle ShorT, M.D., F.R.C.S. 